DOI: 10.12731/2658-6649-2019-11-5-112-117

УДК 577.334

\title{
ОСОБЕННОСТИ \\ ПРО- И АНТИОКСИДАНТНОЙ \\ СИСТЕМ ЭРИТРОЦИТОВ БОЛЬНЫХ КОЛОРЕКТАЛЬНЫМ РАКОМ
}

Перепечай Я.И., Смирнова О.В. Титова Н.М., Глазкова М.О., Борисова В.В., Курченко А.Е., Тимофеева А.А., Мишина В.А., Ефимова О.А.

В данной работе изучаются прооксидантные и антиоксидантные проиессы в эритроцитах больных колоректальным раком. О работе АОС судили по содержанию восстановленного глутатиона, активности супероксиддисмутазы, каталазы, глутатионпероксидазы и глутатион-S-трансферазы. Состояние прооксидантной системы оценивали по уровню диеновых конъюгатов и малонового диальдегида. У больных колоректальным раком показано снижение активности антиоксидантных ферментов и интенсификаџия перикисного окисления липидов.

Ключевые слова: Колоректальный рак; антиоксидантная система; перекисное окисление липидов.

\section{FEATURES OF PRO- AND ANTIOXIDANT SYSTEMS OF ERYTHROCYTES OF PATIENTS WITH COLORECTAL CANCER}

Perepechay Ya.I., Smirnova O.V., Titova N.M., Glazkova M.O., Borisova V.V., Kurchenko A.E., Timofeeva A.A., Mishina V.A., Efimova O.A.

In this paper, we study prooxidant and antioxidant processes in the erythrocytes of patients with colorectal cancer. The state of the antioxidant system was assessed by the content of GSH, the activity of SOD, catalase, GPO, GST. The state of the prooxidant system was assessed by the level of diene conjugates and malonic dialdehyde. A decrease in the activity of antioxidant enzymes and the intensification of lipid peroxidation in patients with colorectal cancer has been shown.

Keywords: Colorectal cancer; antioxidant system; lipid peroxidation. 
Колоректальный рак (КРР) в мире занимает третье место по заболеваемости среди мужчин и второе - среди женщин $[1,2]$. КРР относится к числу полиэтиологических заболеваний, возникающих под влиянием внешних и внутренних факторов, основными из которых являются генетическая предрасположенность, наличие хронических воспалительных болезней толстого кишечника, особенности диеты и образа жизни [2]. Известно, что в тканях, пораженных воспалением, накапливаются избыточные количества активных форм кислорода (АФК), приводящие к активации свободнорадикальных реакций. При этом происходит нарушение структуры белков и липидов в клеточных мембранах, изменение вязкости липидного бислоя, конформации мембранных белков, что отражается на функционировании ионных каналов, активности ферментов и сродстве рецепторов с лигандами [3]. Баланс АФК в живом организме поддерживает многокомпонентная антиоксидантная система (АОС). Гиперпродукция АФК, либо не достаточная деятельность АОС могут нарушить баланс проантиоксидантов , что в свою очередь приводит к развитию окислительного стресса, являющегося одним из важнейших патогенетических механизмов возникновения ряда заболеваний, в том числе и колоректального рака. Целью исследования являлось изучение соотношения прооксидантных и антиоксидантных процессов в эритроцитах больных ККР.

\section{Материалы и методы исследования}

В группу изучения были включены 30 пациентов с колоректальным раком, в возрасте от 38 до 71 лет (56 $\pm 6,5$ лет), проходивших лечение в Красноярском краевом клиническом онкологическом диспансере им. А.И. Крыжановского. Всем больным оказано хирургическое пособие в различных объемах. Кровь у больных забиралась в день поступления в стационар и на 7-е сутки после операции. Контрольная группа состояла из 70 практически здоровых людей. Объектом исследования служили эритроциты.

Состояние АОС определялось по содержанию GSH, а также активности ферментов - СОД, каталазы, глутатионпероксидазы и глутатион-S-трансферазы. Для оценки прооксидантных процессов измерялось содержание продуктов перекисного окисления липидов (ПОЛ) - диеновых конъюгатов и малонового диальдегида (МДА).

Определение активности антиоксидантных ферментов, содержания восстановленного глутатиона, диеновых конъюгатов и малонового диальдегида производилось спектрофотометрическим методом на спектрофотометре Spekol 1300 (Германия) [4]. 
Статистическая обработка данных проводилась с помощью пакетов прикладных программ Statistica 10.0. При описании выборки вычислялись медианы (Ме) и интерквартильный размах (C25-C75). Достоверность различий между показателями независимых выборок оценивали по критерию Манна-Уитни $(\mathrm{p}<0.05)$.

\section{Результаты исследования и их обсуждение}

Проведенные исследования показали снижение эффективности работы антиоксидантной системы больных КРР независимо от лечения, о чем свидетельствует падение уровня GSH и активности глутатионзависимых ферментов, а так же СОД.

Согласно полученным данным, активность СОД у пациентов с колоректальным раком до лечения достоверно снижена на $26 \%$ ( $<00,05)$, а после на $38 \%(\mathrm{p}<0,01)$ в сравнении с показателями группы здоровых людей.

Содержание восстановленного глутатиона в эритроцитах больных КРР достоверно снижено на $88 \%$ до лечения и на $92 \%$ после $(\mathrm{p}<0,001)$ относительно показателей контрольной группы; активность глутатионпероксидазы у больных КРР до и после лечения ниже чем в группе контроля примерно на $40 \%$ ( $<0,001)$; активность глутатион-S-трансферазы у больных до и после операции достоверно снижена на $48 \%$ и на $56 \%$ соответственно ( $<00,001)$.

На фоне сниженной активности антиоксидантной системы в эритроцитах больных колоректальным раком до лечения достоверно повышен уровень МДА на $115 \%$ ( $<0,001)$, что свидетельствует об интенсификации процессов перекисного окисления липидов. После оперативного лечения, содержание МДА в эритроцитах больных КРР снижается в 1,4 относительно дооперационных показателей, однако остается повышенным в сравнении с соответствующим показателем у здоровых людей на $55 \%(\mathrm{p}<0,01)$.

\section{Заключение}

Полученные данные говорят о снижении эффективности работы антиоксидантной системы больных КРР, о чем свидетельствует падение уровня GSH и активности глутатионзависимых ферментов, СОД и каталазы. На фоне снижения активности антиоксидантных ферментов наблюдается интенсификация перикисного окисления липидов, о чем свидетельствует повышенное содержание вторичного продукта ПОЛ - малонового диальдегида. Таким образом, функционирование антиоксидантной системы в эритроцитах больных колоректальным раком нарушено и неэффективно, действие прооксидантов превалируют над антиоксидантами. 


\section{Сиисок литературы}

1. Федоров В.Э., Поделякин К.А. Эпидемиологические аспекты колоректального рака (обзор) // Медицинский альманах. 2017. №4(49). С. 145-148.

2. Алиев Ф.Ш., Десятов Е.Н., Крутских А.Г. Эпидемиология колоректального рака: мировые и региональные тенденции // Медицинская наука и образование Урала. 2016. № 4. С. 125-128.

3. Окислительный стресс. Прооксиданты и антиоксиданты / Е.Б. Меньщикова и [др.]. М.: Фирма «Слова», 2006. 556 с.

4. Оценка структурно-функционального состояния клетки: метод. указания к практическим занятиям / Н.М. Титова [и др.]. Красноярск: ИПК СФУ. 2009. $60 \mathrm{c}$.

5. Влияние электромагнитных полей на тонус церебральных сосудов и артериальное давление. Разумов А.Н., Бобровницкий И.П., Колесникова И.В., Каспаров Э.В. и др. Вопросы курортологии, физиотерапии и лечебной физической культуры. 2006. № 2. С. 3-5.

6. Хемилюминесцентная активность нейтрофильных гранулоцитов в прогрессировании механической желтухи в зависимости от уровня билирубина и генеза желтухи. Смирнова О.В., Титова Н.М., Каспаров Э.В. и др. Медицинская иммунология. 2016. Т. 18. № 3. С. 269-278.

7. Использование методов нейросетевого моделирования и дискриминантного анализа для оценки состояния иммунного статуса у больных острым нелимфобластным лейкозом. Манчук В.Т., Смирнова О.В. Якутский медицинский журнал. 2010. № 2 (30). С. 77-79.

\section{References}

1. Fedorov V.Je., Podeljakin K.A. Jepidemiologicheskie aspekty kolorektal'nogo raka (obzor) [Epidemiological aspects of colorectal cancer (review)]. Medicinskij al'manah. 2017. №4(49), pp. 145-148.

2. Aliev F.Sh., Desjatov E. N., Krutskih A.G. Jepidemiologija kolorektal'nogo raka: mirovye i regional'nye tendencii [Epidemiology of colorectal cancer: global and regional trends]. Medicinskaja nauka i obrazovanie Urala. 2016. № 4, pp. $125-128$.

3. Men'shhikova E.B. et al. Okislitel'nyj stress. Prooksidanty i antioksidanty [Oxidative stress. Prooxidants and Antioxidants]. M.: Firma «Slova», 2006. 556 p.

4. Titova N.M. et al. Ocenka strukturno-funkcional'nogo sostojanija kletki: metod. ukazanija k prakticheskim zanjatijam [Evaluation of the structural and functional state of the cell: method. instructions for practical exercises]. Krasnojarsk: IPK SFU. 2009. 60 p. 
5. Razumov A.N., Bobrovnickij I.P., Kolesnikova I.V., Kasparov E.V. i dr. Vliyanie elektromagnitnyh polej na tonus cerebral'nyh sosudov i arterial'noe davlenie [The influence of electromagnetic fields on the tone of cerebral vessels and blood pressure]. Voprosy kurortologii, fizioterapii i lechebnoj fizicheskoj kul 'tury [Questions of balneology, physiotherapy and medical physical culture]. 2006. № 2, pp. 3-5.

6. Smirnova O.V., Titova N.M., Kasparov E.V. i dr. Hemilyuminescentnaya aktivnost' nejtrofil'nyh granulocitov v progressirovanii mekhanicheskoj zheltuhi $\mathrm{v}$ zavisimosti ot urovnya bilirubina i geneza zheltuhi [Chemiluminescent activity of neutrophil granulocytes in the progression of obstructive jaundice, depending on the level of bilirubin and the genesis of jaundice]. Medicinskaya immunologiya [Medical immunology]. 2016. V. 18. № 3, pp. 269-278.

7. Manchuk V.T., Smirnova O.V. Ispol'zovanie metodov nejrosetevogo modelirovaniya i diskriminantnogo analiza dlya ocenki sostoyaniya immunnogo statusa u bol'nyh ostrym nelimfoblastnym lejkozom [Using methods of neural network modeling and discriminant analysis to assess the state of the immune status in patients with acute non-lymphoblastic leukemia]. Yakutskij medicinskij zhurnal. 2010. № 2 (30), pp. 77-79.

\section{ДАННЫЕ ОБ АВТОРАХ}

Перепечай Ярослава Игоревна ${ }^{1}$, аспирант

Смирнова Ольга Валентиновна ${ }^{1,2}$, доктор медицинских наук, профессор, заведующая лабораторией патофизиологии

Титова Надежда Митрофановна ${ }^{2}$, кандидат биологических наук, доцент ИФБиБТ

Глазкова Маргарита Олеговна ${ }^{2}$, Борисова Виолетта Валерьевна², Курченко Андрей Евгеньевич ${ }^{2}$, Тимофеева Анна Андреевна ${ }^{2}$, Мишина Виктория Александровна², Ефимова Оксана Андреевна ${ }^{2}$, студенты кафедры медицинской биологии ИФБиБТ

${ }^{1}$ ФИЦ КНЦ СО РАН НИИ МПС

${ }^{1}$ ул. Партизана Железняка, 32, г. Красноярск, 660022, Российская Федерация

${ }^{2} C \Phi У$

${ }^{2}$ пр. Свободный 79, г. Красноярск, 660041, Российская Федераџия peyaig@yandex.ru

\section{DATA ABOUT THE AUTHORS}

Perepechay Yaroslava Igorevna ${ }^{1}$, graduate student

Smirnova Olga Valentinovna ${ }^{1,2}$, Doctor of Medical Sciences, Professor, Head of the Pathophysiology Laboratory 
Titova Nadezhda Mitrofanovna ${ }^{2}$, Candidate of Biological Sciences, Associate Professor, Institute of Fundamental Biology and Biotechnology

Glazkova Margarita Olegovna ${ }^{2}$, Borisova Violetta Valerievna ${ }^{2}$, Kurchenko Andrei Evgenievich ${ }^{2}$, Timofeeva Anna Andreevna², Mishina Viktoria Alexandrovna ${ }^{2}$, Efimova Oksana Andreevna ${ }^{2}$, students of Institute of Fundamental Biology and Biotechnology

${ }^{1}$ Federal research center "Krasnoyarsk scientific center" Siberian branch of the Russian Academy of Sciences Research Institute of Medical Problems of the North

13G, Partizana Zheleznyaka Str., Krasnoyarsk, 660022, Russian Federation ${ }^{2}$ Siberian Federal University

279, Prospect Svobodnyj, Krasnoyarsk, 660041, Russian Federation peyaig@yandex.ru 